\title{
"TINJAUAN YURIDIS PERATURAN DAERAH KOTA SAMARINDA NOMOR 14 TAHUN 2009 TENTANG PENYELENGGARAAN ADMINISTRASI KEPENDUDUKAN DAN PENCATATAN SIPIL DI KOTA SAMARINDA DALAM PENCATATAN ANAK DI LUAR PERKAWINAN"
}

\author{
Iqbal Adiyatma dan Dinny Wirawan Pratiwie \\ adiyatmaiqbal08@gmail.com,dinnipratiwie@uwgm.ac.id \\ Fakultas Hukum Universitas Widya Gama Mahakam Samarinda
}

\begin{abstract}
ABSTRAK
Administrasi Kependudukan dan Pencatatan Sipil bagi penduduk merupakan sebuah pelayanan oleh pemerintah diharapkan dapat memberikan pemenuhan atas hak-hak administratif penduduk melalui peran aktif Pemerintah dan Pemrintah Daerah. Salah satu diantaranya merupakan pencatatan anak di luar perkawinan, di Kota Samarinda wewenang pencatatan tersebut diberikan kepada Kantor Dinas Kependudukan dan Pencatatan Sipil Kota Samarinda berdasarkan Undang-Undang Nomor 14 Tahun 2009 Tentang Penyelenggaraan Administrasi Kependudukan Dan Pencatatan Sipil Di Kota Samarinda berupa pengakuan dan pengesahan. Pencatatan anak di luar perkawinan dihrapkan dapat memberikan pemenuhan hak kenegaraan oleh negara dan memberikan perlindungan status secara hukum bagi anak yang lahir tidak secara perkawinan baik agama ataupun secara hukum negara.
\end{abstract}

Kata Kunci : Administrasi Kependudukan, Pencatatan Sipil, Anak Luar Perkawinan, Peraturan Daerah.

\begin{abstract}
ABSTRACK
Administration of Population and Civil Registration for residents is a service by the government is expected to provide fulfillment of the administrative rights of the population through the active role of Government and Local Government. One of them is the registration of children born without marriage, in the city of Samarinda The registration authority is given to the Office of Population and Civil Registration Samarinda based on Law Number 14 Year 2009 on the Implementation of Administration of Population and Civil Registration In the city of Samarinda in the form of recognition and validation. Recording a child outside marriage dihrapkan can provide the fulfillment of rights state by state and provide legal protection status for children born in a marriage is not legal either religion or country.
\end{abstract}

\section{Keywords : Population Administration, Civil registration, Children Born Without Marriage, Local Regulation}




\section{PENDAHULUAN}

\section{A. Latar Belakang}

Undang-Undang Nomor 24 Tahun

2013 Tentang Perubahan Tentang Undang-Undang Nomor 23 Tahun 2006 Tentang Administrasi Kependudukan sebagaimana telah dijelaskan pada paragraf pertama alinean ke satu bahwa Negara Kesatuan Republik Indonesia beradasarkan Pancasila dan UndangUndang Dasar Negara Republik Indonesia Tahun 1945 pada hakekatnya berkewajiban memberikan pengakuan serta perlindungan hukum bagi rakyat indonesia atas peristiwa yang dialami.

Salah satu bentuk peristiwa yang dialami oleh seseorang adalah berupa peristiwa penting, maksud dari peristiwa penting ini dijelakan dalam UndangUndang Nomor 24 Tahun 2013 Tentang Perubahan Atas Undang-Undang Nomor 23 Tahun 2006 Tentang Administrasi Kependudukan Pasal 1 angka 17 yaitu, yang dimaksud peristiwa penting adalah kejadian yang dialami oleh seseorang meliputi kelahiran, kematian, lahir mati, perkawinan, perceraian, pengakuan anak, pengesahan anak, pengangkatan anak, perubahan nama dan perubahan status kewarganegaraan.

Pemerintah sebagai penyelenggaran administrasi pemerintahan yang dilaksanakan berdasar pada asas umum pemerintahan yang baik, bertanggung jawab kepada masyarakat untuk melaksanakan administrasi kependudukan dan pencatatan sipil, untuk mendata setiap penduduk yang ada di Indonesia secara merata, sesuai dengan peraturan perundang-undangan yang berlaku.

Administrasi Kependudukan sebagai suatu sistem, bagi penduduk diharapkan dapat memberikan pemenuhan atas hak-hak administratif penduduk dalam pelayanan publik serta memberikan perlindungan yang berkenaan dengan penertiban dokumen kependudukan tanpa ada perlakuan yang diskriminatif melalu peran aktif Pemerintah dan Pemerintah Daerah.

Berdasarkan Undang-Undang Nomor 23 Tahun 2014 tentang Pemerintah Daerah Pasal 12 ayat (2) huruf $\mathrm{f}$, administrasi kependudukan dan pencatatan sipil merupakan Urusan Pemerintahan Wajib yang tidak berkaitan dengan pelayanan dasar. Oleh karena itu, Pemerintah Kota Samarinda dalam pelaksanaanya, diatur dalam Peraturan Daerah Nomor 14 Tahun 2009 Tentang Penyelenggaraan Administrasi Kependudukan dan Pencatatan Sipil di Kota Samarinda.

Sebagai proses pendataan administrasi penduduk secara menyeluruh, sudah menjadi tugas dari Dinas Kependudukan Dan Pencatatan Sipil di Kota Samarinda, untuk menjalankan tanggung jawabnya untuk mendata secara menyeluruh bagi setiap masyarakat di ruang lingkup kewenangan dari Pemerintah Kota Samarinda, terutama setiap anak dan/ataupun anak yang baru lahir dan tidak terkecuali anak yang lahir diluar perkawinan yang sah menurut undangundang dan agama sebagai salah satu bentuk peristiwa penting yang dimaksud dengan Undang-Undang Nomor 24 Tahun 2013 yang pelaksanaannya di Kota Samarinda diatur Peraturan Daerah Nomor 14 Tahun 2009 dalam pasal 49 dan 50.

Undang - Undang No.1 Tahun 1974 Pasal 42 Tentang Perkawinan menjelaskan bahwa anak yang sah adalah anak yang dilahirkan dalam atau sebagai akibat perkawinan yang sah. Hal ini otomatis menjadikan anak yang telarhir di luar perkawinan yang sah 
sebagai anak yang tidak sah diakui oleh undang-undang. Selain itu dalam Undang-Undang No. 1 Tahun 1974 juga menjelaskan dalam pasal 43, anak di luar perkawinan hanya mempunyai hubungan perdata dengan ibunya dan keluarga ibunya sehingga ayahnya terbebas dari beban tanggung jawab dan kewajiban.

Menurut Isyana Konoras dalam jurnal hukumnya yang berjudul Perlindungan Hukum Terhadap Anak Di Luar Nikahmenjelaskan, anak pada umumnya (baik anak sah maupun anak diluar nikah) menurut hukum memiliki hak-hak keperdataan yang melekat dengan dirinya, oleh karena ia adalah seorang anak (orang). Di dalam Kitab Undang-Undang Hukum Perdata ditentukan dalam Pasal 1 bahwa, menikmati hak perdata tidaklah tergantung pada hak kenegaraan.Berdasarkan pada Pasal 1 Kitab Undang-Undang Hukum Perdata tersebut, hak-hak keperdataan berbeda dari hak-hak kenegaraan, walaupun pada dasarnya hak-hak kenegaraan itu juga mengatur hak-hak keperdataan. ${ }^{1}$

Hak-hak kenegaraan seperti hak sipil, hak ekonomi, hak politik, dan lainlainnya yang menurunkan antara lain hak untuk dijamin persamaan kedudukan di hadapan hukum (equality before the law), berkaitan erat dengan hak keperdataan bahwa jaminan persamaan kedudukan di hadapan hukum berlaku bagi semua orang, semua suku, semua agama tanpa adanya ketentuan yang diskriminatif oleh negara dan praktiknya dalam masyarakat. ${ }^{2}$ Oleh karena itu, dibutuhkan suatu aturan pemerintah yang mengatur tentang anak di luar perkawinan ini terutama dibagian pencatatan anak di luar perkawianan

\footnotetext{
${ }^{1}$ Konoras I. K, Perlindungan Hukum Terhadap Anak Di luar nikah, vol. 1/no.2/AprilJuni/2013- Edisi Khusus, hlm. 47 - 48
}

untuk melindungi hak - hak kenegaraan anak tersebut dalam hal administrasi dan pencatatan sipil sebagai bentuk pengelolaan dan pengembangan pelayanan publik dalam rangka pemenuhan kebutuhan masyarakat sebagai tugas bagi setiap pemerintahan di daerah ${ }^{3}$.

Sebagaimana dijelaskan di atas, dimana bahwa sebagai salah satu bentuk pelayanan publik dan proses pembangunan daerah, bentuk adminstrasi dan pencatatan sipil merupakan suatu kewajiban oleh setiap daerah. Pemerintah Kota Samarinda juga menetapkan peraturan yang mengatur tentang pencatatan anak di luar perkawinan sebagaimana diatur dalam Peraturan Daerah Kota Samarinda Nomor 14 Tahun 2009 Tentang Pencatatan Penyelenggaraan Administrasi Kependudukan Dan Pencatatan Sipil Di Kota Samarinda mengatur tentang prosedur pencatatan adminstrasi anak di luar perkawinan dalam pasal 49, dan 50 yang meliputi pengakuan dan pengesahan dari anak yang lahir di luar perkawinan yang sah.

Pada umumnya, sebagaimana diatur dalam Peraturan Daerah Nomor 14 Tahun 2009, Pemerintah Kota Samarinda memberikan katagori pencatatan anak di luar perkawinan yaitu berupa pengakuan dan pengesahan sebagai bentuk hak anak untuk mendapatkan pemenuhan administrasi dan pencatatan sipil yang sah.

\section{B. Rumusan Masalah}

Berdasarkan uraian latar belakang tersebut di atas, maka permasalahan yang ditunjuk dalam penulisan skripsi ini adalah sebagai berikut:

\footnotetext{
${ }^{2}$ Ibid

${ }^{3}$ Juniarso Ridwan \&Achmad Sodik Sudarjat, Hukum Administrasi Negara dan Kebjiakan Pelayanan Publik, Bandung, hlm 83
} 
1. Bagaimana mekanisme pencatatan anak di luar perkawinan di Kota Samarinda?

2. Apa kendala yang dihadapi dalam pencatatan anak di luar perkawinan di Kota Samarinda

\section{Tujuan dan Manfaat Penelitian}

Pelaksanaan Administrasi

Kependudukan dan Pencatatan.

Administrasi Negara terutama dalam pelaksanaan Administrasi Kependudukan dan Pencatatan Sipil.Sebagai sumbangan bagi Pemerintah Daerah Kota Samarinda dalam proses pendataan dan pencatatan administrasi catatan sipil terhadap anak di luar kawin di Kota Samarinda pelaksanaan Administrasi

Kependudukan dan Pencatatan

Adapun manfaat dalam penelitian ini bahwa Hasil penelitian ini diharapkan dapat memberikan sumbangan pengetahuan dalam pengembangan ilmu hukum terutama di bidang Hukum Administrasi Negara terutama dalam Pengesahan anak diluar perkawinan di Kota Samarinda dan untuk mengkaji faktor-faktor apa saja yang menjadi kendala dalam proses pencatatan pengesahan anak di luar perkawinan Di kota Samarinda.

\section{METODE PENELITIAN}

\section{A. Jenis Penelitian}

Jenis penelitian yang digunakan penulis dalam penelitian ini adalah dengan metode yuridis normatif, yang didukung dengan penelitian lapangan.
Adapun yang menjadi tujuan dalam penelitian ini adalah untuk menganalisa, mengkaji dan mengetahui proses mekanisme pencatatan

Menurut Soerjono Soekanto, "metode penelitian hukum normative merupakan suatu cara meneliti bahan berdasarkan studi kepustakaan yang ada."4

\section{B. Sumber Data}

Bahan Hukum Primer, yaitu bahan hukum yang bersifat mengikat ${ }^{5}$, terdiri dari :

a. Undang-Undang Dasar Negara Republik Indonesia Tahun 1945 Amandemen IV.

b. Kitab Undang-Undang Hukum Perdata.

c. Undang-Undang Republik Indonesia Nomor 1 Tahun 1974 Tentang Perkawinan.

d. Undang-undang Republik Indonesia Nomor 39 Tahun 1999 tentang Hak Asasi Manusia.

e. Undang-Undang Republik Indonesia Nomor 24 Tahun 2013 Tentang Administrasi Kependudukan.

f. Undang-Undang Republlk Indonesia Nomor 23 Tahun 2014 Tentang Pemerintahan Daerah.

g. Undang-Undang Republik Indonesia Nomor 30 Tahun 2014 Tentang Administrasi Pemerintahan.

h. Putusan Mahkamah Konstitusi Nomor 46/PUU-VIII/2010.

i. Peraturan Derah Kota Samarinda Nomor 11 Tahun 2008 Tentang Organisasi dan Tata Kerja Dinas Daerah Kota Samarinda

j. Peraturan Daerah Kota Samarinda Nomor 14 Tahun 2009 Tentang

\footnotetext{
${ }^{4}$ Soerjono Soekanto dan Sri Mamuji, Penelitian Hukum Normatif, Suatu Tinjauan Singkat, Jakarta, 2012, hlm. 13 - 14

${ }^{5}$ Bambang Sunggono, op.cit, hlm. 113
} 
k. Penyelenggaraan Administrasi

Kependudukan Dan Pencatatan Sipil Di Kota Samarinda.

Bahan Hukum Sekunder sebagaimana dijelaskan oleh Bambang Sunggono dalam Metode Penelitian Hukum, yaitu bahan hukum yang memberi petunjuk dan kejelasan terhadap bahan hukum primer, yang terdiri dari buku-buku, makalah, artikel, hasil penelitian karya ilmiah lainnya yang berhubungan dengan penelitian ini. $^{6}$

Kemudian Bambang Sunggono juga menjelaskan tentang Bahan Hukum Tersier yaitu berupa bahan hukum yang diperoleh melalui studi kepustakaan, sesuatu yang dapat menjelaskan dari apa yang menjadi penelitian yang terdapat pada sumber hukum primer atau sumber hukum sekunder, seperti kamus bahasa Indonesia, kamus hukum yang berhubungaan dengan permasalahan yang menjadi objek penelitian dalam penulisan ini. ${ }^{7}$

\section{Teknik Pengumpulan Data}

Pengumpulan Data yang dilakukan dalam penelitian ini melalui 2 (dua) cara, yakni melalui studi kepustakaan dan wawancara.

Studi Kepustakaan, penelitian ini dilakukan dengan cara mempelajari, meneliti dan menghimpun data yang diambil dari peraturan perundangundangan yang berkaitan dengan masalah yang diteliti, buku-buku, dokumen-dokumen serta kamus hukum.

Wawancara, yaitu melakukan tanya jawab secara langsung dengan subyek penelitian tentang permasalahan terkait penelitian ini dengan pedoman wawancara. Tujuannya untuk mengumpulkan data dan informasi yang

\footnotetext{
${ }^{6}$ Op.cit
}

berguna bagi penulis dalam penyusunan karya ilmiah terkait mekanisme dan kendala pencatatan anak di luar perkawinan, dalam ruang lingkup Kantor Administrasi Pendudukan dan Catatan Sipil Kota Samarinda.

\section{Analisis Data}

Data yang telah dikumpulkan dari penelitian kepustakaan maupun dari penelitian lapangan selanjutnya dianalisis secara deskriptif kualitatif, yaitu metode analisis data dengan cara mengelompokan dan menyeleksi data yang diperoleh dari penelitian menurut kualitas dan kebenarannya, kemudian dihubungkan dengan teori - teori dari studi kepustakaan sehingga diperoleh jawaban atas permasalahan dalam penelitian ini.

\section{PEMBAHASAN}

\section{A. Mekanisme Pencatatan Anak Di Luar Perkawinan Di Kota Samarinda}

Undang-Undang 39 Tahun 1999

Tentang Hak Asasi Manusia pasal 53 ayat (2) menjelaskan bahwa "setiap anak sejak kelahirannya, berhak atas suatu nama dan status kewarganegaraannya. Terlepas dari mana asal usul anak terebut baik dari perkawinan yang sah oleh Negara ataupun di luarnya.Perkawinan sendiri yang definiskan sebagai perkawinan yang sah oleh agama sebagaimana diatur dalam UndangUndang 1 Nomor 1 Tahun 1974 tentang Perkawinan Pasal 2 ayat (1) dan yang dicatatkan oleh instansi pemerintah yang berwenang meleksanakan tugas pencatatannya Pasal 2 ayat (2)

Anak di luar perkawinan dalam sudut pandang Kantor Administrasi Kependudukan dan Pencatatan Sipil Kota Samarinda adalah anak yang lahir dari ayah dan ibu biologisnya yang

\footnotetext{
${ }^{7}$ Op.cit
} 
menikah hanya sah secara agama dan tidak dicatatkan maupun anak yang lahir dari pasangan ayah dan ibu biologis anak tersebut yang tidak melaksanakan perkawinan secara sah baik secara agama maupun dicatatkan di oleh Kantor Dinas Kependudukan Dan Pecnatatan Sipil Kota Samarinda. Meskipun ada anak yang lahir di luar perkaiwnan ini lantas tidak menghilangkan hak anak tersebut sebagaiman yang diatur oleh Undang-undang Nomor 39 tahun 1999 tentang Hak Asasi Manusia.

Hak Pertama anak setelah dilahirkan adalah identitas yang meliputi nama, orangtua (silisilah keturunan) dan kewerganegaraan yang dituangkan dalam bentuk akta kelahiran. Hak ini akan menuntukan pengakuan, pemenuhan dan perlindungan anak yang lainya seperti hak keperdataan (waris dan nafkah), akses tehadap pendididikan, kesehatan, dan lain-lain.

Di Kota Samarinda, Pencatatan Anak di luar perkawinan menjadi wewenang Kantor Dinas Kependudukan dan Catatan Sipil Kota Samarinda sebagaimana diatur dalaam Peraturan Daerah Kota Samarinda Nomor 14 Tahun 2009 Tentang Penyelenggaraan Administrasi Kependudukan dan Pencatatan Sipil Di Kota Samarinda Pasal 49 dan 50 yang berbentuk pengakuan serta pengesahan anak, untuk melakukan Pencatatan anak diluar perkawinan terlebih dahulu orang tua dari anak terseebut harus memenuhi beberapa syarat sebelum kemudian dicatatakan oleh Kantor Dinas Kependudukan dan Pencatatan Sipil Kota Samarinda.

1. Pengakuan Anak a. Persyaratan Pengakuan Anak

1. Harus Ada persetujuan Ibu kandung dari anak du luar perkawinan

Meski ada ketentuan yang memungkinkan seorang laki-laki atau bapak melakukan pengakuan anak, namun pengakuan itu hanya bisa dilakukan dengan persetujuan ibu. Pasal 284 KUH Perdata menyatakan bahwa suatu pengakuan terhadap anak luar kawin, selama hidup ibunya, tidak akan diterima jika si ibu tidak menyetujui. Pasal 278 KUH Pidanapun mengatur tentang ancaman pidana bagi orang yang mengakui anak luar kawin yang bukan anaknya.

\section{Akta Kelahiran Anak}

Oleh karena sebagaimana diatur dalam Undang-Undang Nomor 1 Tahun 1974 tentang Perkawinan pasal 42 yang menjelaskan bahwa anak yang dilahirkan di luar perkawinan hanya memiliki hubungan perdata dengan ibunya, maka pengakuan hanya dapat dilakukan oleh sang ayah dengan mencantumkan akta anak tersebut yang hanya mencantumkan nama dari ibu biologis sang anak, dengan persetujuan oleh ibu

\section{Penetapan Permohonan dari Pengadilan Negeri maupun Pengadilan Agama tempat tinggal ibu dari anak di luar perkawinan}

Untuk penetapan status anak yang dimohoinkan poengakuannya, sebelum dicatatkan kedua orang tua dari anak yang lahir di luar perkawinan harus terlebih dahulu memohonkan status anak tersebut kepada Pengadilan Negeri (bagi yang non-muslim) serta Pengadilan Agama (bagi orang tua yang beragama islam).

4. Surat Pernyataan pengakuan anak luar kawin dari sang ayah Menyangkut pencatatan anak di luar kawin demi kepentingan pemenuhan hak-hak bagi anak, anak diluar perkawinan dapat dimohonkan pengakuan oleh seorang ayah dengan surat pernyataan resmi dari sang ayah bilamana dapat dibuktikan secara sah berdasarkan ilmu pengetahuan dan 
teknologi atau alat bukti lain menurut hokum mempunyai hubungan darah. Sebagaimana putusan yang dikeluarkan oleh Mahkamah Konstitusi Nomor 46/PUU-VIII/2010 tanggal 17 februari 2012.

Apabila Ayah dari anak bersangkutan tidak memiliki keinginan atau menyangkal untuk mengakui anak di luar perkawinan tersebut, maka ibu kandung dari anak luar kawin tersebut dapat memohonkan kepada pengadilan negeri untuk secara hukum membuktikan bahwa anak terebut memang bukan anak biologisnya dengan bantuan teknologi dan ilmu pengetahuan sebagai alat bantu pembuktian.

\section{b. Pengakuan Anak Hasil Nikah Siri}

Untuk anak di hasill dari nikah siri maka pencatatan pengakuan anak masih tetap dapat dilakukan hanya apabila istri dari ayah anak dari luar perkawinannya yang sah tersebut menyetujui untuk dilakukan pengakuan anak tersebut, dan dicantumkan dalam catatan pinggir Kartu Keluarga sang ayah telah mengakui anak tersebut, hal ini juga tidak terlepas dari persetujuan sang ibu kandung yang memiliki hubungan perdata dengan anak di luar perkawinan tersebut.

\section{Pengesahan Anak}

Pengesahan anak di luar perkawinan dapat dikatakan merupakan tahap lanjutan dari pencatatan pengakuan anak di luar perkawinan, pengesahan anak di luar perkawinan hanya dapat dilakukan apabila orang tua dari anak tersebut sudah sceara sah melakukan perkawinan menurut agama masing-masing serta sudah dicatatkan oleh instansi dinas terkait yang berwenangn melakukan pencatatan.

Adapun persyaratan yang harus dipenuhi bagi orang tua untuk mencatatkan pengesahan anknya adalah: a. Surat Pengantar RT/RW dan diketahui Kepala Desa/Lurah

Sebagaai tahap awal persyaratan yang dipenuhi orang tua yang ingin mencatatkan pengesahan anaknya harus meminta surat pengatar dari rt tempat tinggal kedua orang tua anak tersebut untuk di data di wilayah tempat tinggal orang tua anak terebut yang kemudian diteruskan kepada Kepala Desa/Lurah yang berwenang.

b. Kutipan Akta Kelahiran

Oleh karena anak di luar perkawinan hanya memiliki akta kelahiran yang hanya mencantumkan nama dari ibu anak tersebut, sebab itu kutipan akta kelahiran dibutuhkan untuk kemudian diberikan catatan pinggir oleh petugas instansi Dinas Kependudukan dan Pencatatan Sipil yang berwenang yang menytakan sahnya anak tersebut dari pasnangan orang tua anak yang telah melakukan perkawinan sah secara hukum dan agama, dimana dalam kutipan akta terssebut mencantumkan pula nama dari sang ayah.

c. Foto Kopi Akta perkawinan

Sebagai tanda bukti orang tua dari anak yang lahir di luar perkawinan telah melakukan pernikahan secara sah hokum dan agama. Untuk kemudian Kantor Dinas Kependudukan dan Pencatatan sipil melakukan pencatatanr anak yang telah disahkan kedalam register perkawinan orang tua anak tersebut.

d. Foto Kopi Kartu Keluarga

Foto kopi kartu keluarga diberikan oleh orang tua anak yang akhirnya telah sah menjadi pasangan suami istri untuk kemudian diberikan kutipan catatan pinggir pengesahan anak.

Tata Cara pelaporan pengakuan dan pengesahanm dilakukan dengan cara pemohon mengisi dan menyerahkan lampiran Formulir Pelapopran Pengesahan Anak dengan mencantumkan berkas terkait pengakuan ataupun pengesahan yang telah lengkap 
kepada instansi Kantor Dinas Kependudukan Dan Pencatatan Sipil terkait. Untuk kemudian mencantumkan catatan pinggir pada register akta perkawinan, dan membuat catatan pinggir pada register akta kelahiran dan kutipan akta kelahiran dengan lama penyelesaian terhitun 14 hari kerja sejak dipenuhinya semua persyaratan.

Berdasarkan hasil analisa penulis, dari prespektif Hukum Administrasi Negara yang dijalankan seseuai dengan Asas Umum Pemerintahan Yang Baik, maka dalam mekanisme pelaksanaan Administrasi Kependudukan dan Pencatatan Sipil di Kota Samarinda dalam pencatatan anak luar kawin telah dilaksanakan dengan baik dan berjalan sebagaimana mestinya sesuai Peraturan Daerah Nomor 14 Tahun 2009 tentang Penyelenggaraan Administrasi Kependudukan dan Pencatatan Sipil Di Kota Samarinda. Namun seiring dengan perkembangan masyarakat Kota Samarinda, tetap terjadi kendala bagi Kantor Dinas Kependudukan dan Pencatatan Sipil Kota Samarinda dalam mencatatkan anak luar kawin. Kendala tersebut yang kemudian akan penulis bahas di pembahasan selanjutnya.

\section{B. Kendala Yang Dihadapi Dalam Pencatatan Anak Di Luar Perkawinan Di Kota Samarinda}

1. Identitas Orang Tua Anak Luar Kawin Yang tidak Lengkap

Bagi orang tua anak luar kawin yang identitasnya tidak jelas, maka hal ini sangat menyulitkan bagi Dinas Kependudukan dan Pencatatan Sipil Kota Samarinda untuk mencatatkan anak luar kawin mereka, minimnya berkas identitas yangharus dicantumkan dalam berkas pengajuan pencatatan pengakuan anak oleh orang tua, bagi Dinas Kepndudukan dan Pencatatan Sipil Kota Samarinda akan sangat mengahmbat proses penctatan anak luar kawin karena yang pertama harus dicantumkan dalam pengajuan pencatatan adalah identitas lengkap orang tua yang sah untuk mengetahui asal usul yang jerlas dan lengkap identitas orang tua yang akan mengajukan pencatatan anak luar kawin.

2. Ayah dari anak luar kawin telah memiliki istri yang sah sebelumnya memiliki anak dengan ibu kandung anak luar kawin

Untuk anak hasil dari orang tua yang dimana sang ayah masih memiliki istri yang sah baginya, stastu kedudukan perdata yang diatur dalam Undang Undang Nomot 1 Tahun 1974 yang hanya memberikan status keperdataan kepada anak tersebut. Ayah dari anak luar kawin tersebut bisa saja mengakui anaknya sesuai dan mengajukan pencatatan ke Dinas Kependudukan dan Catatan Sipil, akan tetapi menjadi kendala apabila ayah dari anak luar kawin tersebut masih memiliki istri yang sah, dikarenakan anak tersebut merupakan hasil dari perbuatan zina. Pengakuan dapat dilakukan bila istri sah dari ayah menyetujui adanya pengakuan, akan tetapi tanpa persetujuan hal ini akan berdampak pada anak statusnya tidak diakui dan tidak dapat dicatatkan.

3. Tidak ada bukti nikah dari orang tua anak luar kawin

Orang tua yang hanya melakukan pernikahan siri ataupun orang tua yang tidak dapat mencantumkan bukti asli pernikahan mereka, tidak akan dapat mencatatkan pengesahan anak hasil perkawinan kedalam kutipan akta kelahiran anak tersebut, karena dalam pencatatan pengesahan anak luar kawin bukti nikah orang tua yang sah secara agama dan dicatatkan oleh negara merupakan bukti wajib sebagai syarat pencatatan pengesahan anak luar kawin.Hal ini umum terjadi kepada pasangan yang menikah hanya secara siri, ataupun pernikahannya tidak diakui 
oleh hokum baik secara agama maupun hukum positif.

\section{Pandangan masyarakat Kota Samarinda yang menganggap rendah status anak luar kawin}

Sikap masyarakat yang masih menjunjung tinggi nilai-nilai adat ketimuran dimana kentalnya hukum agama di masyarakat Kota Samarinda, menganggap bahwa memeiliki anak di luar perkawinan merupakan sebuah aib di dalam keluarga.Hal ini tentu berdampak kepada stastu anak, hak-hak, serta kedudukan anak di masyarkat social yang dikucilkan. Anak luar kawin akan mendapatkan tempat yang tidak layak di masyarakat

Analisa penulis dalam pembahasan kendala yang dihadapi dalam pencatatan sipil anak luar perkawinan di Kota samarinda adalah,akanselalu ada kendala dalam pelaksanaan administrasi kependudukan dan pencatatan sipil dikarenakan pelayanan administrasi kependudukan merupakan bentuk dari pelayanan yang diberikan Pemerintah Daerah menyangkut register penduduk, harus ada data peristiwa yang dilaporkan oleh penduduk terlebih dahulu sebelum akhirnya dilakukan pencatatan sipil. Pertumbuhan penduduk yang semakin padat akan menyulitkan proses pencatatan serta data yang tidak lengkap pada akhirnya akan membuat pencatatan anak luar perkawinan tidak dapat dilakukan.

\section{PENUTUP}

\section{A. Kesimpulan}

Pencatatan anak luar kawin di Samarinda dilaksanakan oleh Kantor Dinas Kependudukan dan Pencatatan Sipil Kota Samarinda yang dilaksanakan berdasarkan Undang-Undang Nomor 14 Tahun 2009 Tentang Pelaksanaan Administrasi Kependudukan dan
Pencatatan Sipil Di Kota Samarinda. Pelaksanaan pencatatan dibagi menjadi pengakuan dan pengesahan ank luar kawin, dan terdapat berbagai prosedur yang harus dipenuhi orang tua anak luar kawin ketika ingin mencatatkan status anak mereka. Persyaratan tersebut diantaranya jika yang dimohopnkan pencatatan adalah pengakuan adalah harus ada persetujuan ibu, akta kelahiran anak, penetapan permohonan dari Pengadilan Negeri ataupun Pengadilan Agama tempat tinggal ibu dari anak luar kawin serta surat pernyataan pengakuan anak luar kawin dari ayah kandung. Sedangkan jika yang dimohonkan adalah pengesahan anak maka yang wajib dicantumkan oleh orang tua adalah surat pengantar RT/RW dan diketahui Kepala Desa/lurah, kutipan akta kelahiran, foto kopi akta perkawinan orang tua, serta foto kopi keluarga.

Kendala yang menjadi penghambat bagi Dinas kependudukan dan Pencatatan Sipil Kota Samarinda dalam melaksanakan pencatatan anak di luar perkawinan yaitu identitas orang tua yang kurang lengkap, ayah dari anak luar kawin telah memiliki istri yang sah sebelum memiliki anak dengan ibu kandung nak luar kawin, tidak ada bukti nikah dari orang tua anak luar kawin, serta pandangan masyarakat Kota Samairinda yang menganggap rendah stastus anak luar kawin.

\section{B. Saran}

Dalam pelaksanaan pencatatan anak luar kawin oleh kantor Dinas Kependudukan dan Pencatatan Sipil Kota Samarinda, hendaknya memberikan pelayanan yang baik, cepat dan proses yang lancar untuk membantu bagi orang tua yang ingin mencatatkan anak luar kawin, akan tetapi harus berdasarkan peraturan dan undangundang yang berlaku. Pelatihan serta 
Diklat kepada pegawai juga akan dapat membantu Kantor Dinas Kependudukan dan Pencatatan Sipil Kota Samarinda memberikan pelayanan yang terbaik dalam pencatatan anak luar kawin.

Hendaknya sosialisasi terhadap masyarakat Kota Samarinda oleh Kantor Dinas Kependudukan dan Pencatatan Sipil Kota Samarinda dalam pentingnya pencatatan anak luar kawin terus dilakukan demi memenuhi hak-hak anak, baik hak kenegaraan maupun hak perdata, sangat penting dilakukan sehingga orang tua dari anak tidak mengabaikan status anak mereka. Selain sosialisasi, Kantor Dinas Kependudukan dan Penctatan sipil juga berkewajiban membantu bagi orang tua yang ingin mencatatkan stastu anak mereka sehingga proses menjadi mudah dan cepat.

\section{DAFTAR PUSTAKA}

\section{Buku}

Amir Syarifudin, Hukum Perkawinan Islam di Indonesia, Kencana, Jakarta, 2011

GadjongAgussalimAndi, Pemerintahan daerah, Kajian Politik dan Hukum, Ghalia Indonesia, Bogor, 2007

Makhfudz. M, Hukum Administrasi Negara, Graha Ilmu, Yogyakarta, 2013

Muliadi, Hak Asasi Manusia:

Hakekat, Konsep dan Implikasinya Dalam Perspektif Hukum Dan Masyarakat, Refika Aditama, Bandung, 2007

Perangin Effendi, Hukum Waris, Raja Grafindo Persada, Jakarta, 2002

Priamsmoro Suyanti, Pasang Surut Pengangkatan Kepala Daerah: Pergesran Politik, Cv. Pandu Nusantara, Samarinda, 2006
RidwanJuniarso, Achmad Sodik Sudrajat, HAN \& Kebijakan Pelayanan Publik, Bandung, 2009

Sadjijono, Bab-Bab Pokok Hukum Administrasi Negara, LakBangPrESSindo, Yogyakarta, 2011

SentosaPanji, Administrasi Publik, Teori dan Aplikasi Good Governance, Refika Aditama, Bandung 2012

Situmorang Viktor M, Catatan Sipil di Indonesia,Sinar Grafika, Jakarta, 2002

Sjarif Surini Ahlan dan Nurul Elmiyah, Hukum Kewarisan Perdata Barat, Prenoda Media group, Jakarta, 2006

SoekantoSoerjonodanSri

Mamuji, PenelitianHukumNormatif, SuatuTinjauanSingkat, $\quad$ Raja GrafindoPersada, Jakarta, 2012

Soimin Soedharyo, Hukum Orang dan Keluarga, Sinar Grafika, Jakarta, 2002

Sunggono Bambang, Metodelogi Penelitian Hukum, Rajawali Press, Jakarta, 2012

Tanuwidjaja Henny, Hukum Waris Menurut $B W$, RefikaAditama, Bandung, 2012 
PeraturanPerundang-undangan

Undang-Undang Dasar Negara

Republik Indonesia Tahun 1945

Amandemen IV

Kitab Undang-Undang

HukumPerdata

Undang-Undang Republik

Indonesia Nomor 1 Tahun 1974 Tentang

Perkawinan

Undang-Undang Nomor 39

Tahun 1999 Tentang Hak Asasi Manusia Undang-Undang Republik

Indonesia Nomor 24 Tahun 2013

Tentang Adminsitrasi Kependudukan

Undang-Undang Republik

Indonesia Nomor 23 tahun 2014 Tentang

Pemerintahan Daerah

Undang-Undang Republik

Indonesia Nomor 30 Tahun 2014

Tentang Administrasi Pemerintah

Putusan Mahkamah Konstitusi

Nomor 46/PUU-VIII/2010

Peraturan Derah Kota Samarinda

Nomor 11 Tahun 2008 Tentang

Organisasidan Tata Kerja Dinas Daerah

Kota Samarinda

Peraturan Daerah Kota

SamarindaN omor 14 Tahun 2009

Tentang Penyelenggaraan Administrasi

Kependudukan Dan PencatatanSipil Di

Kota Samarinda

\section{Internet}

Dewi Prihartiningsih, Tinjauan Hukum Pengakuan Dan Pengesahan Atas Anak Luar Kawin Menjadi Anak Yang Diakui Secara Sah, 2013, diakses padahttp://digilib.esaunggul.ac.id/tinjau an-hukum-pengakuan-dan-pengesahanatas-anak-luar-kawinmenjadi-anakyang-diakui-secara-sah-354.html

http://blogpki.blogspot.co.id/2013/06/ad ministrasi-kependudukan.html http://dokumen.tips/documents/catatansipil-penduduk.html http://dianchocho.blogspot.co.id/2 014/04/pengertian-fungsi-dan-asaspemerintahan.html

Isyana K. Konoras, PerlindunganHukumTerhadapAnak Di luarnikah, vol.1/no.2/April-Juni/2013EdisiKhusus, diaksespada http://www.google.com

http://vicko36.blogspot.co.id/2012 /04/catatan-sipil.html

http://dandyhernadypahusa.blogsp ot.co.id/2013/09/asas-asas-umumpemerintahan-yang-baik_10.html

http://pemerintah.net/asas-asasumum-pemerintahan-yang-baik-aupb/

\section{Wawancara}

Wawancara dengan Ibu Dra.Hj. Siti Aisyah. Kepala Seksi Bidang Pencatatan Sipil Kantor Dinas Kependudukan dan Pencatatan Sipil Kota Samarinda tanggal 10 Oktober 2016

Arsip

Profil Kantor Dinas

Kependudukan dan Pencatatan Sipil Kota Samarinda, 2014 